\title{
Age associated oxidative damage in lymphocytes
}

\author{
Nandeslu Gautam, ${ }^{1}$ Subhasis Das, ${ }^{1}$ Santanu Kar Mahapatra, ${ }^{1}$ Subhankari Prasad Chakraborty, ${ }_{1}$ Pratip Kumar Kundu² \\ and Somenath Roy ${ }^{1, *}$ \\ IImmunology and Microbiology Laboratory; Department of Human Physiology with Community Health; ${ }^{2}$ Department of Microbiology; Vidyasagar University; \\ Midnapore, West Bengal India
}

Key words: lymphocyte, oxidative stress, antioxidant enzymes, aging

\begin{abstract}
Abbreviations: SOD, superoxide dismutase; CAT, catalse; GPx, glutathione peroxidase; ROS, reactive oxygen species; MDA, malondialdehyde; PC, protein carbonyls; BHP, tert-butyl hydroperoxide; SDS, sodium dodecyl sulfate; TBARS, thiobutiric acid reactive substances; PC, protein carbonyl; DNPH, 2, 4-dinitrophenyl hydrazine; TCA, trichloro acetic acid; GSH, reduced glutathione; DTNB, 5', 5'-dithio (bis)-2-nitrobenzoic acid; GSSG, oxidized glutathione; EDTA, ethylene diamine tetra acetate; NADPH, nicotinamide adenine dinucleotide phosphate; GR, glutathione reductase; GST, glutathione-s-transferase
\end{abstract}

\begin{abstract}
Lymphocytes are an important immunological cell and have been played a significant role in acquired immune system; hence, may play in pivotal role in immunosenescence. Oxidative stress has been reported to increase in elderly subjects, possibly arising from an uncontrolled production of free radicals with aging and decreased antioxidant defenses. This study was aimed to evaluate the level of lipid-protein damage and antioxidant status in lymphocytes of healthy individuals to correlate between oxidative damage with the aging process. Twenty healthy individuals of each age group (11-20; 21-30; 31-40; 41-50; and 51-60 years) were selected randomly. Blood samples were drawn by medical practitioner and lymphocytes were isolated from blood samples. Malondialdehyde (MDA), protein carbonyls (PC) level were evaluated to determine the lipid and protein damage in lymphocytes. Superoxide dismutase (SOD), catalase (CAT), glutathione and glutathione dependent enzymes were estimated to evaluate the antioxidant status in the lymphocytes. Increased MDA and PC levels strongly support the increased oxidative damage in elderly subject than young subjects. The results indicated that, balance of oxidant and antioxidant systems in lymphocytes shifts in favor of accelerated oxidative damage during aging. Thus oxidative stress in lymphocytes may particular interest in aging and may play important role in immunosenescence.
\end{abstract}

\section{Introduction}

During the last decades, much research has been directed towards establishing correlations between oxidative damage, antioxidant defense systems and aging. Aging, a complex phenomenon, is an inevitable biological process that is generally characterized by the declining ability to respond to stress, increasing homeostatic imbalance and increase risk of disease. Because of these phenomenon, death is an ultimate consequence of aging. The aging process includes the accumulation of changes with time and a decline of the organism response to these changes. Aging of the immune system, termed immunosenescence, is characterized by a time-dependent functional decline of immunity leading to an onward immunodeficiency. ${ }^{1-4}$ Aging of the immune system involves many changes in all aspects of the immune response. T-lymphocyte functions are especially influenced by aging and the changes occurring in these cells have been associated with alterations in the intracellular signaling pathways. ${ }^{5}$ However, phagocytic cells do not change throughout life while others have observed a senescent decrease or increase in their functions. A general feature of the aging or senescence process is a progressive physiological deterioration with time leading to an impairment of the homeostasis, vulnerability to disease and ultimately to death of the organism. ${ }^{6}$ The free radical theory of aging proposes that age-dependent deterioration in cell function is related to accumulation molecular oxidative damage, caused by reactive oxygen. An increase in production of reactive radicals, particularly as a result of mitochondrial dysfunction has been recognized as a major cause of oxidative stress. ${ }^{7,8}$ However; age-associated alterations in the antioxidant status could also contribute to increased oxidative stress in aging. Reactive oxygen species (ROS) are implicated in aging and in various degenerative disorders. ${ }^{910}$ These ROS are capable of initiating and promoting oxidative damage in the form of lipid peroxidation, protein oxidation and DNA damage. ${ }^{12,13}$ Lipid peroxidation is known to cause cellular injury by inactivation of membrane enzymes and receptors, depolymerization of polysaccharide, as well as protein cross-linking and fragmentation. ${ }^{14}$

To attenuate such a rampant attack, appropriate anti-oxidant defenses arise to protect against damage from ROS. The first line 


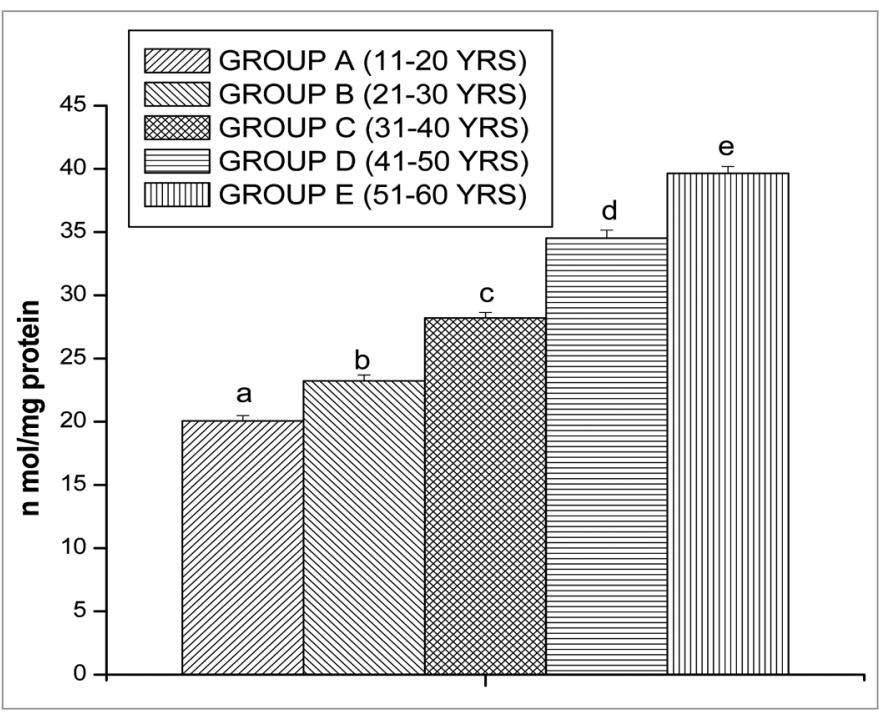

Figure 1. MDA levels in lymphocyte of different age group of human subjects were estimated using UV-Vis Spectrophotometer. Data are expressed as mean $\pm S E M, n=20$. The difference between Group $A-E$ were analyzed with Student's t-test. Values not sharing a common superscript letter $(A-E)$ are stastically significant at the level of $p<0.05$.

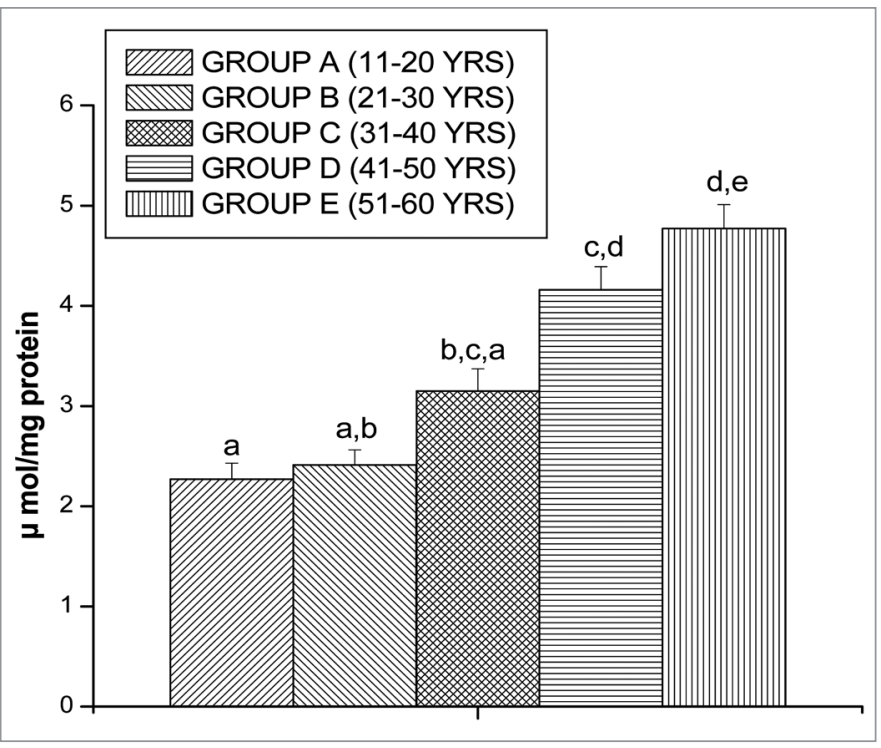

Figure 2. PC levels in lymphocyte of different age group of human subjects were estimated using UV-Vis Spectrophotometer. Data are expressed as mean $\pm S E M, n=20$. The difference between Group $A-E$ were analyzed with Student's t-test. Values not sharing a common superscript letter (a-e) are stastically significant at the level of $p<0.05$.

anti-oxidant system includes enzymes, such as superoxide dismutase (SOD), reduced glutathione peroxidase (GPx) and CAT, which are re-enforced by nonenzymatic anti-oxidants, reduced glutathione (GSH), protein- $\mathrm{SH}$, vitamin $\mathrm{C}, \mathrm{E}, \beta$-carotene and uric acid. During normal oxygen metabolism the concentration of free radicals is controlled by various antioxidants and a balance exists between pro-oxidant and antioxidant process. ${ }^{15}$ Changes in antioxidant capacities like hydrophilic radical scavengers (ascorbate, urate and glutathione), lipophilic radical scavengers (tocopherols, carotenoids), metal chelators and antioxidant enzymes like SOD, CAT and GPx activities have been demonstrated in aging. ${ }^{16}$

Lymphocytes are important immunological cells, present in blood in large quantity, has played a significant role in acquired immune system. These immune cells use ROS for carrying out their normal functions but an excess amount of ROS can attack cellular components that lead to cell damage. Previous report from our laboratory on immune cells, macrophage and lymphocytes, clearly established that ROS generation and lower antioxidants status in cell leads to cellular oxidative damage. ${ }^{12,17}$ Linton and Dorshkind provide an overview of age-related changes in lymphocyte development and function and discuss current controversies in the field of aging research. ${ }^{18}$ Several other studies have explored the effects of aging on total antioxidant capacity of plasma and tissues. They showed reduced or unchanged antioxidant defense. ${ }^{19-23}$ Based on the report on oxidative stress theory and immunosenescence, there is no direct report on human lymphocytes. So, in the present study, we attempted to document the effects of aging on the oxidative damage on lymphocytes by quantifying lipid peroxidation, protein oxidation and different antioxidant status in healthy individuals.

\section{Results}

In the present study, we investigated the oxidative damage occurs in lymphocytes of healthy individual of different age groups. The antioxidant status in lymphocytes was assessed by measuring the enzymatic and non enzymatic antioxidants activity.

Lipid peroxidation and protein oxidation level. Lipid peroxidation and protein oxidation are the two important determinants to assess the cellular damage. Lipid peroxidation and protein oxidation in lymphocytes was measured in terms of MDA and PC, respectively. MDA levels also shows significantly increased in lymphocytes of Group B $(15.89 \pm 0.43 \mathrm{n} \mathrm{mol} / \mathrm{mg}$ protein, $\mathrm{p}<0.05)$, Group C $(21.99 \pm 0.47 \mathrm{n} \mathrm{mol} / \mathrm{mg}$ protein, $\mathrm{p}<0.05)$, Group D $(28.62 \pm 0.52 \mathrm{n} \mathrm{mol} / \mathrm{mg}$ protein, $\mathrm{p}<0.05)$ and in Group E $(33.63 \pm 0.42 \mathrm{n} \mathrm{mol} / \mathrm{mg}$ protein, $\mathrm{p}<0.05)$, respectively, as compared to Group A $(12.35 \pm 0.37 \mathrm{n} \mathrm{mol} / \mathrm{mg}$ protein, $\mathrm{p}<0.05$ ) (Fig. 1).

Increased PC levels were found in lymphocytes of Group B $(5.13 \pm 0.58 \mu \mathrm{mol} / \mathrm{mg}$ protein, $\mathrm{p}<0.05)$, Group C $(7.02 \pm 0.67$ $\mu \mathrm{mol} / \mathrm{mg}$ protein, $\mathrm{p}<0.05)$, Group $\mathrm{D}(9.05 \pm 1.12 \mu \mathrm{mol} / \mathrm{mg}$ protein, $\mathrm{p}<0.05)$ and in Group E $(12.02 \pm 1.34 \mu \mathrm{mol} / \mathrm{mg}$ protein, $\mathrm{p}<0.05)$ by respectively as compared to Group A $(3.06 \pm 0.53 \mu$ $\mathrm{mol} / \mathrm{mg}$ protein, $\mathrm{p}<0.05)$ (Fig. 2).

Glutathione level. Glutathione is an important antioxidant in cellular system. So, to understand glutathione level, we have measured reduced glutathione (GSH) and oxidized glutathione (GSSG) level. Age related decline was observed in the GSH level, the results are shown in Figure 3. There was significant decreased in GSH value for Group B $(21.36 \pm 0.54 \mu \mathrm{gm} / \mathrm{mg}$ protein, $\mathrm{p}<0.05)$, for Group C ( $14.45 \pm 1.10 \mu \mathrm{gm} / \mathrm{mg}$ protein, $\mathrm{p}<0.05)$, for Group $\mathrm{D}(10.53 \pm 0.76 \mu \mathrm{gm} / \mathrm{mg}$ protein, $\mathrm{p}<0.05)$ and for Group $\mathrm{E}$ 
$(6.88 \pm 0.26 \mu \mathrm{gm} / \mathrm{mg}$ protein, $\mathrm{p}<0.05)$ in comparison with Group A (23.81 $\pm 0.6 \mu \mathrm{gm} / \mathrm{mg}$ protein, $\mathrm{p}<0.05)$, respectively.

GSSG levels in lymphocytes also decreased significantly for Group B $(9.53 \pm 0.40 \mu \mathrm{gm} / \mathrm{mg}$ protein, $\mathrm{p}<0.05)$, for Group C $(7.34 \pm 0.31 \mu \mathrm{gm} / \mathrm{mg}$ protein, $\mathrm{p}<0.05)$, for Group D $(4.6 \pm$ $0.20 \mu \mathrm{gm} / \mathrm{mg}$ protein, $\mathrm{p}<0.05)$ and for Group E $(2.28 \pm 0.20$ $\mu \mathrm{gm} / \mathrm{mg}$ protein, $\mathrm{p}<0.05)$ in comparison with Group A (12.25 $\pm 0.42 \mu \mathrm{gm} / \mathrm{mg}$ protein, $\mathrm{p}<0.05$ ), respectively (Fig. 4).

Antioxidant enzymes status. The glutathione peroxidase (GPx), glutathione reductase (GR), glutathione-s-transferase (GST), SOD and CAT activity were measured to understand the antioxidant status of different group of lymphocytes.

GPx activities were observed in all the different age groups of lymphocytes. The results are shown in the Figure 5. The GPx activity decreased significantly for Group B $(13.15 \pm 0.27 \mathrm{n} \mathrm{mol} /$ $\mathrm{min} / \mathrm{mg}$ protein, $\mathrm{p}<0.05)$, for Group $\mathrm{C}(11.04 \pm 0.36 \mathrm{n} \mathrm{mol} /$ $\mathrm{min} / \mathrm{mg}$ protein, $\mathrm{p}<0.05)$, for Group D $(7.06 \pm 0.35 \mathrm{n} \mathrm{mol} / \mathrm{min} /$ $\mathrm{mg}$ protein, $\mathrm{p}<0.05)$ and for Group E $(4.77 \pm 0.30 \mathrm{n} \mathrm{mol} / \mathrm{min} /$ $\mathrm{mg}$ protein, $\mathrm{p}<0.05)$ in comparison with Group A $(15.10 \pm 0.33$ $\mathrm{n} \mathrm{mol} / \mathrm{min} / \mathrm{mg}$ protein, $\mathrm{p}<0.05)$, respectively. GR activity was significantly decreased in lymphocytes of Group B (18.89 \pm 0.36 $\mathrm{n} \mathrm{mol} / \mathrm{min} / \mathrm{mg}$ protein, $\mathrm{p}<0.05)$, in Group C $(14.76 \pm 0.39 \mathrm{n}$ $\mathrm{mol} / \mathrm{min} / \mathrm{mg}$ protein, $\mathrm{p}<0.05)$, in Group D $(11.58 \pm 0.32 \mathrm{n} \mathrm{mol} /$ $\mathrm{min} / \mathrm{mg}$ protein, $\mathrm{p}<0.05)$ and in Group $\mathrm{E}(7.38 \pm 0.27 \mathrm{n} \mathrm{mol} /$ $\mathrm{min} / \mathrm{mg}$ protein, $\mathrm{p}<0.05)$, respectively as compared to Group $\mathrm{A}(21.22 \pm 0.34 \mathrm{n} \mathrm{mol} / \mathrm{min} / \mathrm{mg}$ protein, $\mathrm{p}<0.05)$ (Fig. 6). GST activity was significantly decreased in lymphocytes of Group B $(9.55 \pm 0.20 \mathrm{~m} \mathrm{~mol} / \mathrm{min} / \mathrm{mg}$ protein, $\mathrm{p}<0.05)$, in Group C $(7.22$ $\pm 0.29 \mathrm{~m} \mathrm{~mol} / \mathrm{min} / \mathrm{mg}$ protein, $\mathrm{p}<0.05)$, in Group $\mathrm{D}(5.16 \pm$ $0.27 \mathrm{~m} \mathrm{~mol} / \mathrm{min} / \mathrm{mg}$ protein, $\mathrm{p}<0.05)$ and in Group E $(3.37 \pm$ $0.28 \mathrm{~m} \mathrm{~mol} / \mathrm{min} / \mathrm{mg}$ protein, $\mathrm{p}<0.05)$, respectively as compared to Group A $(11.86 \pm 0.28 \mathrm{~m} \mathrm{~mol} / \mathrm{min} / \mathrm{mg}$ protein, $\mathrm{p}<0.05)$ (Fig. 7).

CAT activity was observed in all the different age groups of lymphocytes. The results are shown in the Figure 8. The CAT activity decreased significantly for Group B $(28.45 \pm 0.83 \mathrm{n} \mathrm{mol} /$ $\mathrm{min} / \mathrm{mg}$ proteins, $\mathrm{p}<0.05)$, for Group C $(19.66 \pm 1.28 \mathrm{n} \mathrm{mol} /$ $\mathrm{min} / \mathrm{mg}$ proteins, $\mathrm{p}<0.05)$, for Group D $(14.16 \pm 1.26 \mathrm{n} \mathrm{mol} /$ $\mathrm{min} / \mathrm{mg}$ proteins, $\mathrm{p}<0.05)$ and for Group E $(9.59 \pm 0.85 \mathrm{n} \mathrm{mol} /$ $\mathrm{min} / \mathrm{mg}$ proteins, $\mathrm{p}<0.05)$ in comparison with Group A (35.32 $\pm 0.62 \mathrm{n} \mathrm{mol} / \mathrm{min} / \mathrm{mg}$ proteins, $\mathrm{p}<0.05)$, respectively. SOD activity was observed in all the different age groups of lymphocytes. The results are shown in the Figure 9. The SOD activity decreased significantly for Group B $(20.16 \pm 0.50 \mathrm{U} / \mathrm{mg}$ protein, $\mathrm{p}<0.05)$, for Group C $(15.83 \pm 0.55 \mathrm{U} / \mathrm{mg}$ protein, $\mathrm{p}<0.05)$, for Group D $(11.73 \pm 0.60 \mathrm{U} / \mathrm{mg}$ protein, $\mathrm{p}<0.05)$ and for Group E $(7.23 \pm 0.52 \mathrm{U} / \mathrm{mg}$ protein, $\mathrm{p}<0.05)$ in comparison with Group A $(18.73 \pm 0.47 \mathrm{U} / \mathrm{mg}$ protein, $\mathrm{p}<0.05)$, respectively.

\section{Discussion}

Lymphocytes, an important immunological cell, have played a significant role in acquired immune system; hence, may play in pivotal role in immunosenescence. The immune cell functions are specially linked to ROS generation and are strongly influenced by the redox potential. Therefore the oxidant/antioxidant

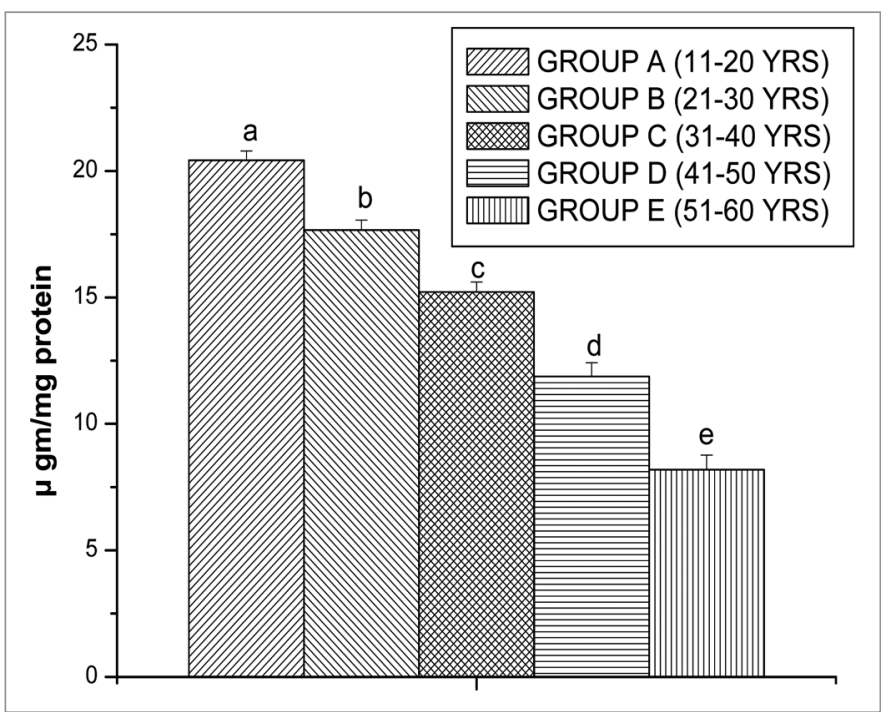

Figure 3. GSH levels in lymphocyte of different age group of human subjects were estimated using UV-Vis Spectrophotometer. Data are expressed as mean $\pm S E M, n=20$. The difference between Group $A-E$ were analyzed with Student's t-test. Values not sharing a common superscript letter (a-e) are stastically significant at the level of $p<0.05$.

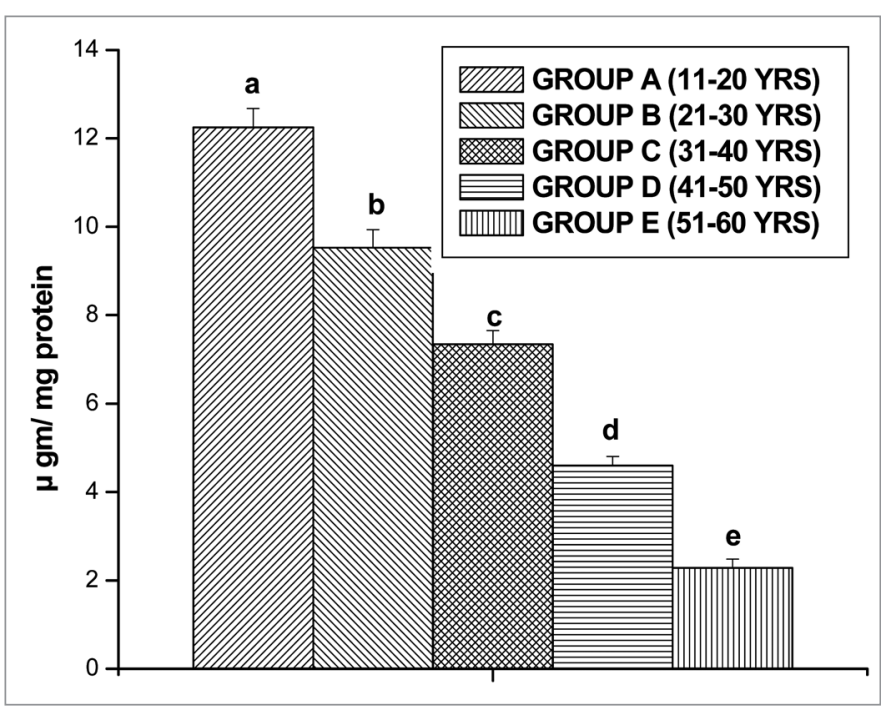

Figure 4. GSSG levels in lymphocyte of different age group of human subjects were estimated using UV-Vis Spectrophotometer. Data are expressed as mean $\pm S E M, n=20$. The difference between Group $A-E$ were analyzed with Student's t-test. Values not sharing a common superscript letter (a-e) are stastically significant at the level of $p<0.05$.

balance is an important determinant of immune cell activity. The antioxidant levels in immune cells play a pivotal role in protecting them against oxidative stress and therefore preserving their adequate function. When a disturbance in the pro-oxidant antioxidant balance (redox status) occurs in favor of the former, the potential for tissue damage due to oxidative stress ensues. ${ }^{24}$ Aging and age-related diseases are associated with oxidative stress from the over-production of ROS. 


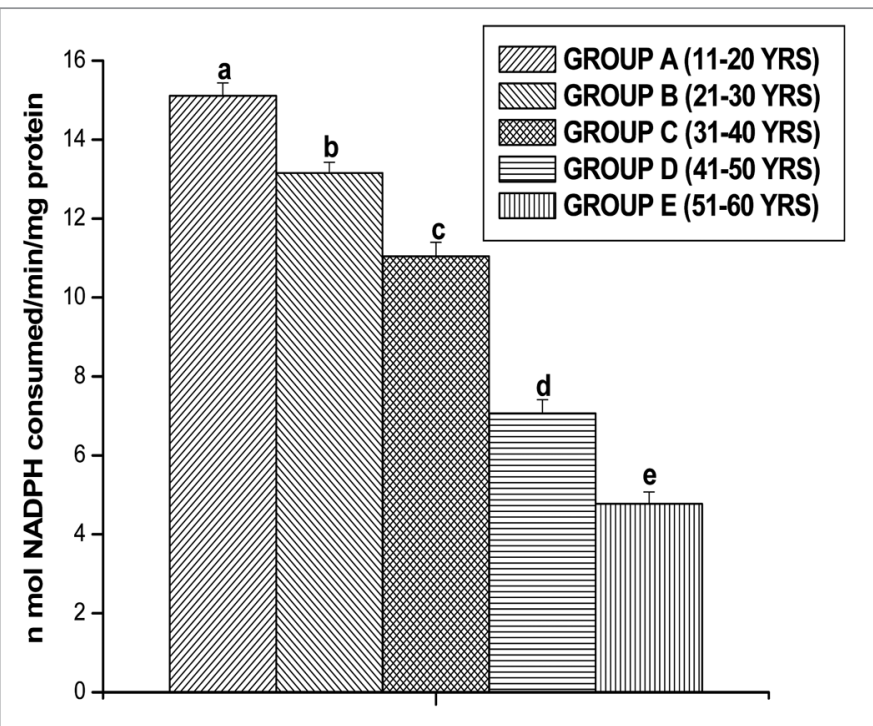

Figure 5. $\mathrm{GP}_{\mathrm{x}}$ activities in lymphocyte of different age group of human subjects were estimated using UV-Vis Spectrophotometer. Data are expressed as mean $\pm S E M, n=20$. The difference between Group A-E were analyzed with Student's t-test. Values not sharing a common superscript letter (a-e) are stastically significant at the level of $p<0.05$.

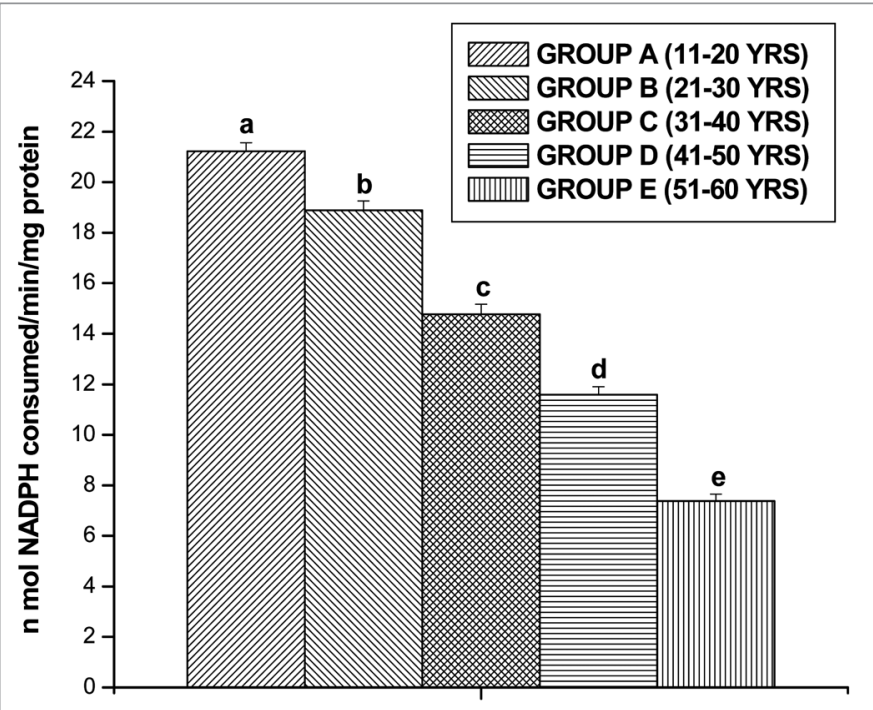

Figure 6. GR activity in lymphocyte of different age group of human subjects was estimated using UV-Vis Spectrophotometer. Data are expressed as mean $\pm S E M, n=20$. The difference between Group $A-E$ were analyzed with Student's t-test. Values not sharing a common superscript letter (a-e) are stastically significant at the level of $p<0.05$.

In the present study, we investigated the oxidative damage in human lymphocytes during aging. Lipid peroxidation is one of the important phenomenons and has been implicated in a number of deleterious effects, such as, increased osmotic fragility, decreased membrane rigidity and cellular deformation. ${ }^{25}$ Hence, we have measured the lipid peroxidation in all groups. It has been observed that, the lipid peroxidation level increased significantly in lymphocytes with aging (Fig. 1). Current studies on cellular injury implicate peroxidation of polyunsaturated fatty acids (PUFA), leading to the degradation of phospholipids as an index of cellular deterioration. ${ }^{26} \mathrm{PC}$ formation has been proposed to be an early marker for protein oxidation. ${ }^{27}$ However, available knowledge on PC formation as a function of age is limited in humans with aging. Some investigators have reported that, PC content increased in lymphocytes, muscle biopsy specimens, fibroblasts and eye lens of elderly subjects. ${ }^{28-31}$ In this study, we detected a significant increase in lymphocytes PC levels in elderly subjects from Groups C, D and E (Fig. 2), as previously reported. $^{32}$

The results strongly suggest that a shift in the redox balance occurs between pro-oxidant and anti-oxidant in favor of the former during aging. To further support this possibility, we assessed lymphocytes glutathione system levels, a major contributing factor to the maintenance of the redox state, particularly in the leukocytes. Glutathione is an important cellular reductant, which offers protections against free radicals, peroxide and toxic compounds. It is reformed from GSSG by donation of hydrogen from NADPH, the reaction being catalyzed by glutathione reductase (GR). ${ }^{33,34}$ Adequate concentrations of GSH are required for a variety of immune functions. It has been suggested that oxidative stress and deficiency of thiol compounds may play an important pathogenic role in the development of immune deficiency. ${ }^{35-37}$ The present study reported a decline in GSH content in lymphocytes from elder groups like Group $\mathrm{C}, \mathrm{D}$ and $\mathrm{E}$ as compared to younger groups like Group A, B (Fig. 3). Depletion of intracellular GSH may inhibit T-cell function. ${ }^{38}$ Recently, it was reported that, the levels of GSH was decreased in aging in human lymphocytes. ${ }^{39}$ Our findings indicate that total thiol levels in elderly group like C, D and $\mathrm{E}$ are significantly lower than those observed in young. Decreased glutathione levels and GPx activity are coupled to increased oxidative damage to DNA, lipids and proteins. ${ }^{40-44}$ If the level of reduced GSH is high, the oxidative stress is low and the level of lipid peroxidation is low. But with age the level of GSH is falling down and this is seen as raising amounts of MDA. Free radicals can also react with proteins and DNA, in addition to lipids.

The present study reports age-related decline in activities of antioxidant enzymes in lymphocytes from five different age groups. Decreased content of GSH and decline in activities of CAT, SOD, GR, GPx and GST enzymes were the prominent alterations observed in the present investigation with aging (Figs. 3-9). The destruction of reactive oxygen intermediates and of free radicals may be involved with the activities of SOD, CAT, GR, GPx and GSH, as well as supply of NADPH. Our results depicted a parallel decline in GST activity and GSH content with aging. A major factor that affects glutathione homeostasis is its utilization by conjugation primarily via GST. ${ }^{45}$ The ability of GST to alter levels of cellular glutathione in response to production of ROS has been implicated in protection of cells from ROS inducing agent. ${ }^{46}$ There are several conflicting reports on GR activity with aging. Some studies reported a decline in GR activity that accompanies the age-related decrease in GSH content, others have indicated that GR activity either does not 
change or even increase with age. ${ }^{47,48}$ Aerobic cells contain various amounts of two main antioxidant enzymes SOD and CAT. SOD rapidly dismutate superoxide anion $\left(\mathrm{O}_{2}{ }^{-}\right)$to less dangerous $\mathrm{H}_{2} \mathrm{O}_{2}$, which is further degraded by CAT and GPx to water and oxygen. ${ }^{49}$ Decreased CAT activity may compromise the overall antioxidant enzyme defense system. The results of the present study showed a significant fall in SOD activities, in the elderly groups like Group C, D and E. The depletion in SOD activity was may be due to dispose off the free radicals, produced due to aging induced oxidative stress. $\mathrm{H}_{2} \mathrm{O}_{2}$ produced by dismutation of superoxide anion, may have been efficiently converted to $\mathrm{O}_{2}$ by CAT but the enzyme activities showed a marked reduction. The depletion of antioxidant enzyme activity was may be due to inactivation of the enzyme proteins by ROS generation with aging, depletion of the enzyme substrates, and/or downregulation of transcription and translation processes. Our results of decreased CAT and SOD activity in lymphocytes are supported by the reports of Niwa et al. ${ }^{50}$ Garcia et al. also studied the levels of SOD, CAT and GPx and protein oxidative damage in lymphocytes from elderly subjects and reported that oxidative stress produces greater protein oxidative damage in elderly subjects than in young ones. ${ }^{51}$

In summary, the present experiments demonstrate that, the lymphocytes redox status undergoes increased oxidative stress with age, reflected by a decreased antioxidant capacity and an associated increased of biomolecule oxidation. Our results strongly support the presence of increased oxidative stress in elderly subjects. In conclusions, our study demonstrates an agerelated decrease in the total antioxidant capacity of elderly human lymphocytes and provides the indication that this decrease may be involved in the mechanisms of free radical induced damages to lipids and proteins. The conclusions does not only underline the free radical hypothesis of aging, but it is also methodologically important for the evaluation of further clinical studies with regard to basic normal values and with regard to the usage of age matched healthy control groups.

\section{Materials and Methods}

Selection of human subjects. This study was carried out in 100 healthy subjects who were divided according to five different age groups; Group A (11-20 yrs), Group B (21-30 yrs), Group C (31-40 yrs), Group D (41-50 yrs) and Group E (51-60 yrs). All subjects enrolled in this study were asymptomatic and none of them had abnormality on physical examinations and routine laboratory tests. Groups had similar socioeconomic status and dietary habits. All the subjects were from same geographical area and same economic status, non-smokers and non-alcoholic and having same food habit.

These subjects received no medication, including vitamin $\mathrm{E}$ and vitamin C. All subjects gave informed consent. The selection excluded not only individuals with acute infections or chronic diseases, but also excluded healthy individuals undergoing supplementation with antioxidative substances. The study protocol was in accordance with the declaration of Helsinki, and was approved by the ethical committee of Vidyasagar University.

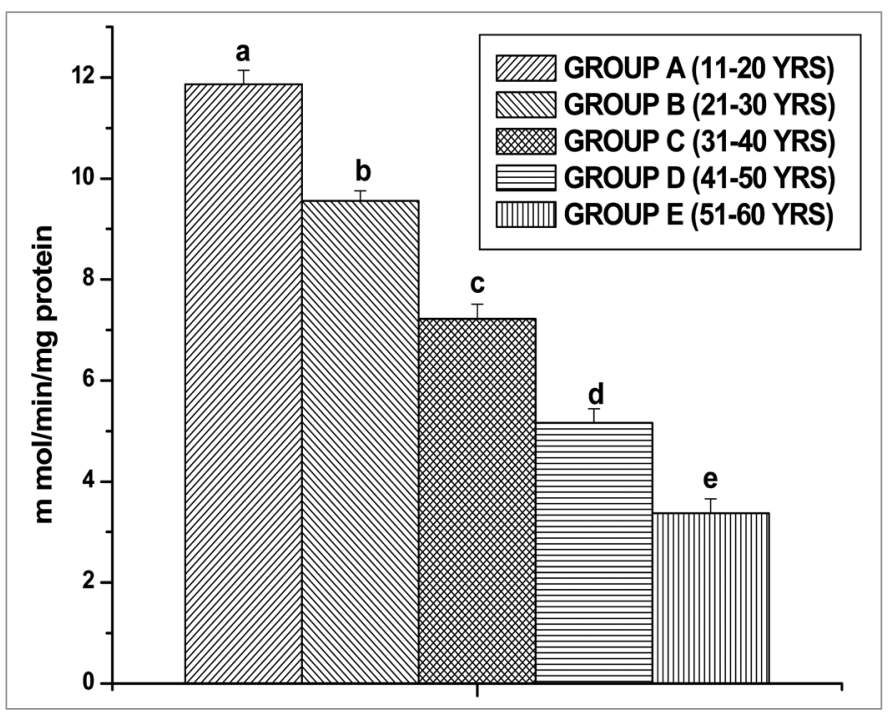

Figure 7. GST activity in lymphocyte of different age group of human subjects was estimated using UV-Vis Spectrophotometer. Data are expressed as mean $\pm S E M, n=20$. The difference between Group $A-E$ were analyzed with Student's t-test. Values not sharing a common superscript letter (a-e) are stastically significant at the level of $p<0.05$.

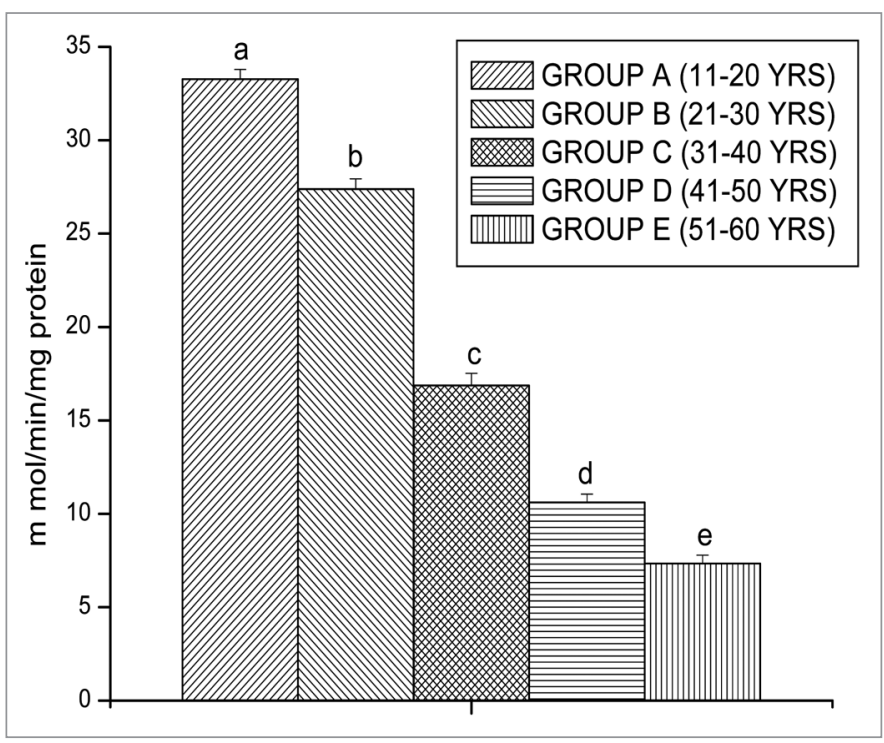

Figure 8. Catalase activities in lymphocyte of different age group of human subjects were estimated using UV-Vis Spectrophotometer. Data are expressed as mean $\pm S E M, n=20$. The difference between Group A-E were analyzed with Student's t-test. Values not sharing a common superscript letter (a-e) are stastically significant at the level of $p<0.05$.

Chemicals and reagents. All fine chemicals were obtained from Sigma Chemical Co., USA. Other chemicals were Used to the analytical/Excelar grade and purchased from Merck Ltd., SRL Pvt. Ltd., Mumbai, India.

Collection of blood samples and separation of lymphocytes. Fasting blood samples were collected from all groups of individuals satisfying the Helsinki protocol. The lymphocytes 


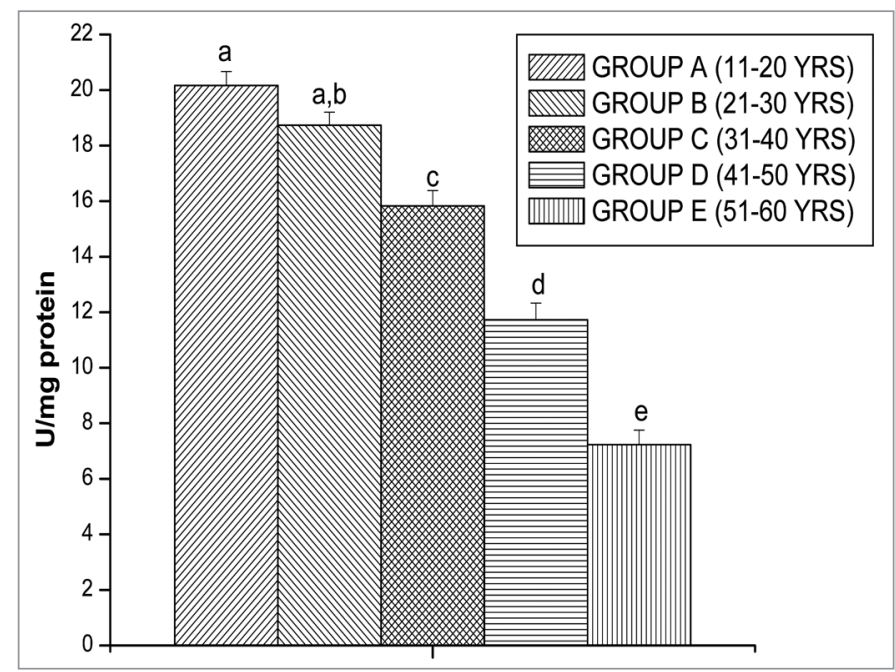

Figure 9. SOD activities in lymphocyte of different age group of human subjects were estimated using UV-Vis Spectrophotometer. Data are expressed as mean $\pm S E M, n=20$. The difference between Group A-E were analyzed with Student's t-test. Values not sharing a common superscript letter $(a-e)$ are stastically significant at the level of $p<0.05$.

were isolated from Heparinized blood samples according to the method of Hudson and Hay. ${ }^{52}$ Blood taken was diluted with phosphate-buffered saline $(\mathrm{pH} 7.0)$ in equal ratio and then layered very carefully on the density gradient (histopaque) in 1:2 ratio, centrifuged at $500 \mathrm{X}$ g for $20 \mathrm{~min}$ and the white milky layer of mononuclear cells, i.e., lymphocytes were carefully removed. The layer was washed twice with the same buffer and then centrifuged at 3,000X $\mathrm{g}$ for $10 \mathrm{~min}$ to get the required pellet of lymphocytes. This pellet was lysed in a hypotonic solution for $45 \mathrm{~min}$ at $37^{\circ} \mathrm{C}$ and then processed for the biochemical estimation.

Biochemical assays. Protein estimation. Protein was determined according to Lowry et al. using bovine serum albumin as standard. ${ }^{53}$

Determination of lipid peroxidation (MDA). Lipid peroxidation was estimated by the method of Ohkawa et al. in cell lysate. ${ }^{54}$ Briefly, the reaction mixture contained Tris- $\mathrm{HCl}$ buffer $(50 \mathrm{mM}$, $\mathrm{pH} 7.4)$, tert-butyl hydroperoxide (BHP) $(500 \mu \mathrm{M}$ in ethanol) and $1 \mathrm{mM} \mathrm{FeSO}_{4}$. After incubating the samples at $37^{\circ} \mathrm{C}$ for 90 min, the reaction was stopped by adding $0.2 \mathrm{ml}$ of $8 \%$ sodium dodecyl sulfate (SDS) followed by $1.5 \mathrm{ml}$ of $20 \%$ acetic acid ( $\mathrm{pH} 3.5$ ). The amount of malondialdehyde (MDA) formed during incubation was estimated by adding $1.5 \mathrm{ml}$ of $0.8 \%$ TBA and further heating the mixture at $95^{\circ} \mathrm{C}$ for $45 \mathrm{~min}$. After cooling, samples were centrifuged and the TBA reactive substances (TBARS) were measured in supernatants at $532 \mathrm{~nm}$ by using $1.53 \times 10^{5} \mathrm{M}^{-1} \mathrm{~cm}^{-1}$ as extinction coefficient. The levels of lipid peroxidation were expressed in terms of $\mathrm{n} \mathrm{mol} / \mathrm{mg}$ protein.

Protein carbonyls contents $(P C)$. Protein oxidation was monitored by measuring protein carbonyl contents by derivatization with 2, 4-dinitrophenyl hydrazine (DNPH). ${ }^{55}$ In general, cell lysate proteins in $50 \mathrm{mM}$ potassium phosphate buffer, $\mathrm{pH} 7.4$, were derivatized with DNPH $(21 \%$ in $2 \mathrm{~N} \mathrm{HCl})$. Blank samples were mixed with $2 \mathrm{~N} \mathrm{HCl}$ incubated at $1 \mathrm{~h}$ in the dark; protein was precipitated with $20 \%$ trichloro acetic acid (TCA). Underivatized proteins were washed with an ethanol:ethyl acetate mixture (1:1). Final pellets of protein were dissolved in 6.0 $\mathrm{N}$ guanidine hydrochloride and absorbance was measured at 370 $\mathrm{nm}$. Protein carbonyls content was expressed in terms of $\mu \mathrm{mol} /$ mg protein.

Determination of reduced glutathione (GSH). Reduced glutathione estimation in the cell lysate was performed by the method of Moron et al..$^{56}$ The required amount of the cell lysate was mixed with $25 \%$ of trichloroacetic acid and centrifuged at 2,000x g for $15 \mathrm{~min}$ to settle the precipitated proteins. The supernatant was aspirated and diluted to $1 \mathrm{ml}$ with $0.2 \mathrm{M}$ sodium phosphate buffer ( $\mathrm{pH} 8.0$ ). Later, $2 \mathrm{ml}$ of $0.6 \mathrm{mM}$ DTNB was added. After 10 minutes the optical density of the yellow-colored complex formed by the reaction of GSH and DTNB (Ellman's reagent) was measured at $405 \mathrm{~nm}$. A standard curve was obtained with standard reduced glutathione. The levels of GSH were expressed as $\mu \mathrm{gm}$ of $\mathrm{GSH} / \mathrm{mg}$ protein.

Oxidized glutathione level (GSSG). The oxidized glutathione level was measured after derevatization of GSH with 2-vinylpyidine according to the method of Griffith. ${ }^{57}$ In brief, with $0.5 \mathrm{ml}$ cell lysate, $2 \mu \mathrm{l}$ 2-vinylpyidine was added and incubates for $1 \mathrm{hr}$ at $37^{\circ} \mathrm{C}$. Then the mixture was deprotenized with $4 \%$ sulfosalicylic acid and centrifuged at $1,000 \mathrm{x}$ g for $10 \mathrm{~min}$ to settle the precipitated proteins. The supernatant was aspirated and GSSG level was estimated with the reaction of DTNB at $412 \mathrm{~nm}$ in spectrophotometer and calculated with standard GSSG curve.

Activity of glutathione peroxidase (GPx). The GPx activity was measured by the method of Paglia and Valentine. ${ }^{58}$ The reaction mixture contained $50 \mathrm{mM}$ potassium phosphate buffer $(\mathrm{pH} 7.0)$, $1 \mathrm{mM}$ EDTA, $1 \mathrm{mM}$ sodium azide, $0.2 \mathrm{mM}$ NADPH, $1 \mathrm{U}$ glutathione reductase and $1 \mathrm{mM}$ reduced glutathione. The sample, after its addition, was allowed to equilibrate for $5 \mathrm{~min}$ at $25^{\circ} \mathrm{C}$. The reaction was initiated by adding $0.1 \mathrm{ml}$ of $2.5 \mathrm{mM} \mathrm{H}_{2} \mathrm{O}_{2}$. Absorbance at $340 \mathrm{~nm}$ was recorded for $5 \mathrm{~min}$. Values were expressed as $\mathrm{n}$ mol of NADPH oxidized to NADP by using the extinction coefficient of $6.2 \times 10^{3} \mathrm{M}^{-1} \mathrm{~cm}^{-1}$ at $340 \mathrm{~nm}$. The activity of GPx was expressed in terms of $\mathrm{n}$ mol NADPH consumed/ $\mathrm{min} / \mathrm{mg}$ protein.

Activity of glutathione reductase (GR). The GR activity was measured by the method of Miwa. ${ }^{59}$ The tubes for enzyme assay were incubated at $37^{\circ} \mathrm{C}$ and contained $2.0 \mathrm{ml}$ of $9 \mathrm{mM} \mathrm{GSSG}$, $0.02 \mathrm{ml}$ of $12 \mathrm{mM} \mathrm{NADPH}, \mathrm{Na}_{4}, 2.68 \mathrm{ml}$ of $1 / 15 \mathrm{M}$ phosphate buffer ( $\mathrm{pH} \mathrm{6.6)}$ and $0.1 \mathrm{ml}$ of cell lysate. The activity of this enzyme was determined by monitoring the decrease in absorbance at $340 \mathrm{~nm}$. The activity of GR was expressed in terms of $\mathrm{n}$ $\mathrm{mol}$ NADPH consumed $/ \mathrm{min} / \mathrm{mg}$ protein.

Activity of glutathione-s-transferase (GST). The activity of GST activity was measured by the method of Habig et al. ${ }^{60}$ The tubes of enzyme assay were incubated at $25^{\circ} \mathrm{C}$ and contained $2.85 \mathrm{ml}$ of $0.1 \mathrm{M}$ potassium phosphate ( $\mathrm{pH} 6.5$ ) containing $1 \mathrm{mM}$ of $\mathrm{GSH}$, $0.05 \mathrm{ml}$ of $60 \mathrm{mM}$ 1-chloro-2, 4-dinitrobengene and $0.1 \mathrm{ml}$ cell lysate. The activity of this enzyme was determined by monitoring the increase in absorbance at $340 \mathrm{~nm}$. The activity of GST was expressed in terms of $\mathrm{m} \mathrm{mol} / \mathrm{min} / \mathrm{mg}$ protein. 
Activity of catalase (CAT). Catalase activity was measured in the cell lysate by the method of Luck. ${ }^{61}$ The final reaction volume of $3 \mathrm{ml}$ contained $0.05 \mathrm{M}$ Tris-buffer, $5 \mathrm{mM}$ EDTA ( $\mathrm{pH}$ 7.0) and $10 \mathrm{mM} \mathrm{H}_{2} \mathrm{O}_{2}$ (in $0.1 \mathrm{M}$ potassium phosphate buffer, $\mathrm{pH}$ 7.0). About $50 \mu \mathrm{l}$ aliquot of the cell lysates were added to the above mixture. The rate of change of absorbance per min at $240 \mathrm{~nm}$ was recorded. Catalase activity was calculated by using the molar extinction coefficient of $43.6 \mathrm{M}^{-1} \mathrm{~cm}^{-1}$ for $\mathrm{H}_{2} \mathrm{O}_{2}$. The level of CAT was expressed in terms of $\mathrm{m} \mathrm{mol} / \mathrm{min} / \mathrm{mg}$ protein.

Activity of superoxide dismutase (SOD). SOD activity was determined from its ability to inhibit the auto-oxidation of pyrogalol according to Mestro Del and McDonald. ${ }^{62}$ The reaction mixture considered of $50 \mathrm{mM}$ Tris (hydroxymethyl) amino

\section{References}

1. Larbi A, Franceschi C, Mazzatti D, Solana R, Wikby A Pawelec G. Aging of the immune system as a prognostic factor for human longevity. Physiology (Bethesda) 2008; 23:64-74.

2. Pawelec G, Larbi A. Immunity and ageing in man: annual review 2006/2007. Exp Gerontol 2008; 43:34-8.

3. Sansoni P, Vescovini R, Fagnoni F, Biasini C, Zanni F, Zanlari $\mathrm{L}$, et al. The immune system in extreme longevity. Exp Gerontol 2008; 43:61-5.

4. Weinberger B, Herndler-Brandstetter D, Schwanninger A, Weiskopf D, Grubeck-Loebenstein B, et al. Biology of immune responses to vaccines in elderly persons. Clin Infect Dis 2008; 46:1078-84

5. Hirokawa K. Age-related changes of signal transduction in T cells. Exp Gerontol 1999; 34:7-18.

6. Ozben T. Oxidative stress and antioxidants in aging. In: Ozben T, Chevion M, editors. Frontiers in neurodegenerative disorder and aging: Fundamental aspects, clinical perspectives and new insights. IOS press 2004; 99-115.

7. Kalous $M$, Drahota Z. The role of mitochondria in aging. Physiol Res 1996; 45:351-9.

8. Van Remmen H, Richardson A. Oxidative damage to mitochondria and aging. Exp Gerontol 2001; 36:957-68.

9. Baynes JW. Role of oxidative stress in development of complications in diabetes. Diabetes1991; 40:405-12.

10. Sagar S, Kallo IJ, Kaul N, Ganguly NK, Sharma BK. Oxygen free radicals in essential hypertension. Mol Cell Biochem 1992; 111:103-8.

11. Ames BN, Shigenaga MK, Hagen TM. Oxidants, antioxidants and the degenerative diseases of aging. Proc Natl Acad Sci USA 1993; 90:7915-22.

12. Das $S$, Neogy $S$, Gautam N, Roy $S$. In vitro nicotine induced superoxide mediated DNA fragmentation in lymphocytes: Protective role of Andrographis paniculata Nees. Toxicol In Vitro 2009; 23:90-8.

13. Kar Mahapatra S, Chakraborty SP, Majumdar S, Bag BG, Roy S. Eugenol protects nicotine-induced superoxide mediated oxidative damage in murine peritoneal macrophages in vitro. Eur J Pharmacol 2009; 623:132-40.

14. Luqman S, Rizvi SI. Protection of lipid peroxidation and carbonyl formation in proteins by capsaicin in human erythrocytes subjected to oxidative stress. Phytother Res 2006; 20:303-6.

15. Golden TR, Hinerfeld DA, Melov S. Oxidative stress and aging: Beyond correlation. Aging Cell 2002; 1:117-23.

16. Krajcovicova-Kudlackova $M$, Dusinska $M$, Valachovicova M, Blazicek P, Paukova V. Products of DNA, protein and lipid oxidative damage in relation to vitamin C plasma concentration. Physiol Res 2006; 55:227-31.
17. Kar Mahapatra S, Chakraborty SP, Das S, Roy S. Methanol extract of Ocimum gratissimum protects murine peritoneal macrophages from nicotine toxicity by decreasing free radical generation, lipid and protein damage and enhances antioxidant protection. Oxid Med Cell Longev 2009; 2:222-30.

18. Linton PJ, Dorshkind K. Age-related changes in lymphocyte development and function. Nature Immunol 2004; 5:133-9.

19. Rodrigues Siqueria I, Fochesatta C, Da Silva Torres IL Dalmaz C, Alexandre Netto C. Aging affects oxidative state in hippocampus, hypothalums and adrenal glands of wistar rats. Life Sci 2005; 78:271-8.

20. Quiles JL, Ochoa JL, Ramirez-Tortosa C, Battino M, Huertas JR, Martin Y, et al. Dietary fat type (virgin olive vs. sunflower oils) affects age related changes in DNA double- strand-breaks, antioxidant capacity and blood lipids in rats. Exp gerontol 2004; 39:1189-98.

21. Kim JW, NO JK, Ikeno Y, YU BP, Choi JS, Yokozawa $\mathrm{T}$, et al. Age related changes in redox status of rat serum. Arch Gerontol Geriat 2002; 34:9-17.

22. Facino RM, Carini M, Aldini G, Berti F, Rossoni G, Bombardelli E, et al. Diet enriched with procyanides enhances antioxidant activity and reduces myocardial post-ischemia damage in rats. Life Sci 1999; 64:627-42.

23. Nakamura YK, Omaye ST. Age related changes of serum lipoprotein oxidation in rats. Life Sci 2004; 23:1265-75.

24. Sies H. Oxidative stress II: Oxidants and antioxidants. Academic press, London 1991.

25. Thampi HBS, Manoj G, Leelamma S, Menon VP. Dietery fiber and lipid peroxidation: effect of dietery fiber on levels of lipids and lipid peroxides in high fat diet. Ind J Exp Biol 1991; 29:563-7.

26. Abou-Donia MB. Ann Rev Pharmacol Toxicol 1981; 21:511-48.

27. Reznick AZ, Packer L. Oxidative damage to proteins: spectrophotometric method for carbonyl assay. Methods Enzymol 1994; 233:359.

28. Garcia-Arumi E, Andreu AL, Lopez-Hellin J, Schwartz S. Effect of oxidative stress on lymphocytes from elderly subjects. Clin Sci 1998; 94:447.

29. Mecocci P, Fano G, Fulle S, MacGarvey U, Shinobu L, Polidori MC, et al. Age-dependent increases in oxidative damage to DNA, lipids and proteins in human skeletal muscle. Free Radic Biol Med 1999; 26:303.

30. Goto S, Nakamura A. Age-associated, oxidatively modified proteins: a critical evaluation. Age 1997; 20:81

31. Stadtman ER, Berlett BS. Reactive oxygen-mediated protein oxidation in aging and disease. Chem Res Toxicol 1997; 10:485.

32. Kasapoglu M, Ozben T. Alterations of antioxidant enzymes and oxidative stress markers in aging. Exp Gerontol 2001; 36:209.

33. Meister A. Glutathione, ascorbate and cellular protection. Cancer Res 1994; 54:1969-75.

34. John RS. Oxidative phosphorylation, mitochondrial proton cycling, free-radical production and aging. Adv Cell Aging Gerontol 2003; 14:35-68.

\section{Acknowledgements}

edge the subjects who participated in this Herzenberg LA, Herzenberg LA. Glutathione deficiency and human immunodeficiency virus infection. Lancet 1992; 339:909-12.

36. Robinson MK, Rodrick ML, Jacobs DO, Rounds JD, Collins KH, Saporoschetz IB, et al. Glutathione depletion in rats impairs T-cell and macrophage immune function. Arch Surg 1993; 128:29-34

37. Aukrust P, Svardal AM, Muller F, Lunden B, Berge RK, Froland SS. Decreased levels of total and reduced glutathione in $\mathrm{CD}^{+}$lymphocytes in common variable immunodeficiency are associated with activation of the tumor necrosis factor system: possible immunopathogenic role of oxidative stress. Blood 1995; 86:1383-91

38. Droge W, Schulze-Osthoff K, Mihm S, et al. Function of glutathione and glutathione disulfide in immunology and immunopathology. FASEB J 1994; 8:1131-8.

39. Van Lieshout EM, Peters WH. Age and gender dependent levels of glutathione and glutathione S- transferases in human lymphocytes. Carcinogenesis 1998; $19: 1873-5$

40. Gotz ME, Freyberger A, Riederer P. Oxidative stress: role in the pathogenesis of Parkinson's disease. J Neural Transm Suppl 1990; 29:241-9.

41. Apostolski S, Marinkovic Z, Nikolic A, Blagojevic D, Spasic MB, Michelson AM. Glutathione peroxidase in amyotrophic lateral sclerosis: the effects of selenium supplementation. J Environ Pathol Toxicol Oncol 1998; 17:325-9.

42. Warita H, Hayashi T, Murakami T, Manabe Y, Abe K. Oxidative damage to mitochondrial DNA in spinal motoneurons of transgenic ALS mice. Brain Res Mol Brain Res 2001; 89:147-52.

43. Volchegorskii IA, Shemyakov SE, Turygin VV, Malinovskaya NV. The age dynamics of monoamine oxidase activity and levels of lipid peroxidation products in the human brain. Neurosci Behav Physiol 2004; 34:303-5.

44. Cakatay U, Telci A, Kayali R, Tekeli F, Akcay T, Sivas A. Relation of oxidative protein damage and nitrotyrosine levels in the aging rat brain. Exp Gerontol 2001; 36:221-9.

45. Hayes JD, McLellan LI. Glutathione and glutathione dependent enzymes represent a co-ordinately-regulated defense against oxidative stress. Free Radic Res 1999; 31:273-300.

46. Tew KD, Ronai Z. GST function in drug and stress response. Drug Resist Updates 1999; 2:143-7.

47. Keogh BP, Allen RG, Pignolo R, Hortron J, Tresini M, Cristofalo VJ. Expression of hydrogen peroxide and glutathione metabolizing enzymes in human skin fibroblasts derived from donors of different ages. J Cell Physiol 1996; 167:512-22.

48. Sahoo A, Chainy GB. Alterations in the activities of cerebral antioxidant enzymes of rat are related to aging. Int J Dev Neurosci 1997; 15:939-48. 
49. Wetscher GJ, Bagchi M, Bagchi D, Perdikis G, Hinder $\mathrm{PR}$, Giaser $\mathrm{K}$, et al. Free radicals production in nicotine-treated pancreatic tissue. Free Radic Biol Med 1995; 18:877-82.

50. Niwa $Y$, Lizawa O, Ishimoto $K$, Akamatsu H, Kanoh T. Age-dependent basal level and induction capacity of copper zinc and manganese superoxide dismutase and other scavenging enzyme activities in leukocytes from young and elderly adults. Am J Pathol 1993; 143:312-20.

51. Garcia AE, Andreu AL, Lopez-Hellin J, Schwartz S. Effect of oxidative stress on lymphocytes from elderly subjects. Clin Sci 1998; 94:447-52.

52. Hudson L, Hay FC. Practical immunology, 3rd, Ed. Blackwell scientific publications; Oxford/London/ Edinburgh/Boston/Melbourne: Blackwell Scientific Publications 1991; 21-2.

53. Lowry OH, Rosenbrough NJ, Farr AL, Randall RJ. Protein measurement with the Folin Phenol Reagent. J Biol Chem 1951; 193:255-75.
54. Ohkawa H, Ohishi N, Yagi K. Assay for lipid peroxides in animal tissues by thiobarbituric acid reaction. Ana Biochem 1979; 95:351-8.

55. Levine RL, Williams JA, Stadtman ER, Shacter E. Carbonyl assay for determination of oxidatively modified proteins. Methods Enzymol 1994; 233:346-57.

56. Moron MS, Kepierre JW, Mannervick B. Levels of glutathione reductase and glutathione-S-transferase activities in rat lung and liver. Biochim Biophys Acta 1979; 582:67-8.

57. Griffith OW. Determination of glutathione and glutathione sulfide using glutathione reductase and 2-Vinyl pyridine. Anal Biochem 1980; 106:207-12.

58. Paglia DE, Valentine WN. Studies on the quantitative and qualitative characterization of erythrocyte glutathione peroxidase. J Lab Clin Med 1967; 70:158-69.
59. Miwa S. Hematology. Mod Med Technol 1972 3:306-10.

60. Habig WH, Pabst MJ, Jakoby WB. Glutathione-Stransferases. The first enzymatic step in mercapyuric acid formation. J Biol Chem 1974; 249:7130-9.

61. Luck H. Catalase. In: Bergmeyer HW, (Ed.), Methods of Enzymatic Analysis, Section 3, Academic Press, New York 1963; 885-94.

62. Mestro Del RF, McDonald W. Oxidative enzymes in tissue homogenates. In Greenwald RA, (Ed.), CRC handbook of methods for oxygen radical research. CRC Press, Boca Raton FL 1986; 291-6. 


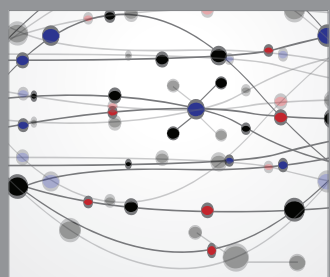

The Scientific World Journal
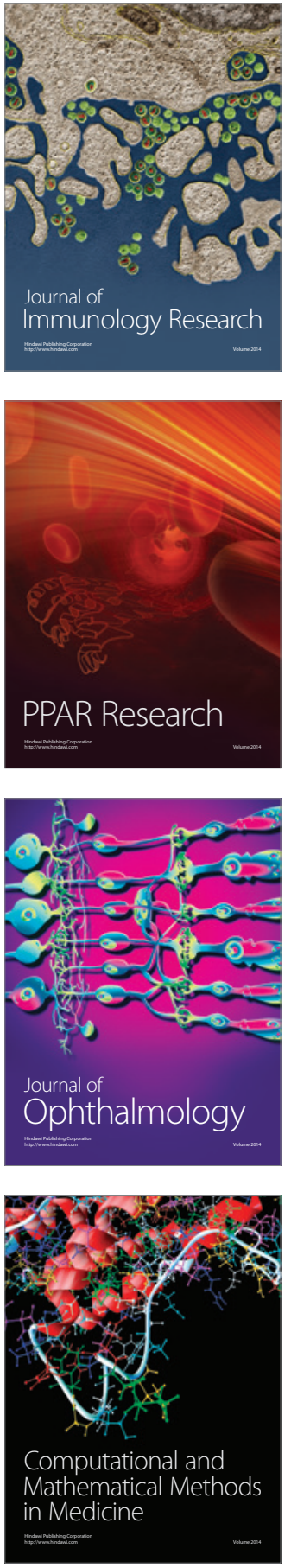

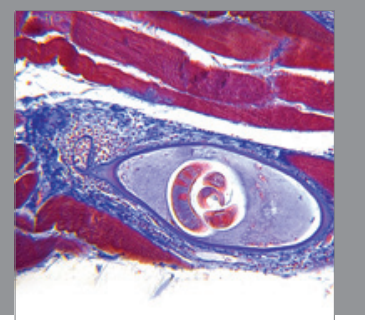

Gastroenterology

Research and Practice
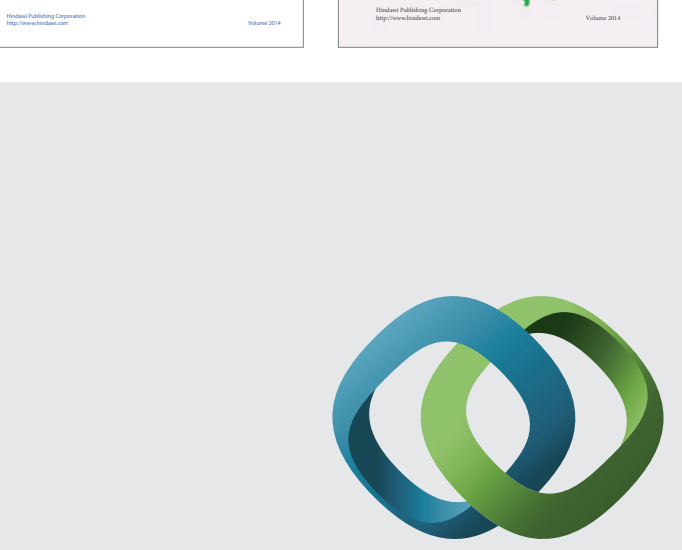

\section{Hindawi}

Submit your manuscripts at

http://www.hindawi.com
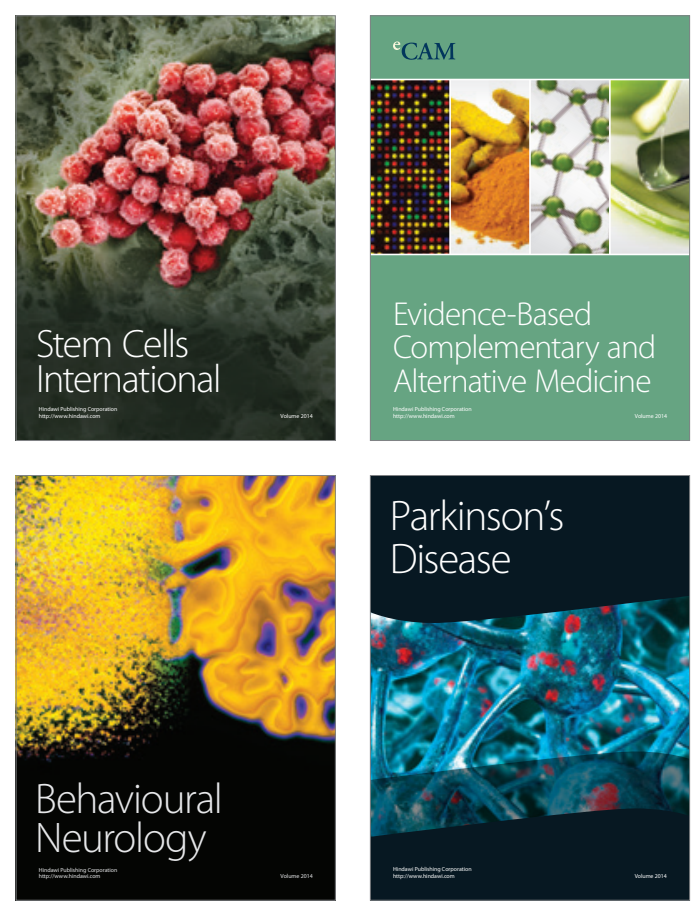

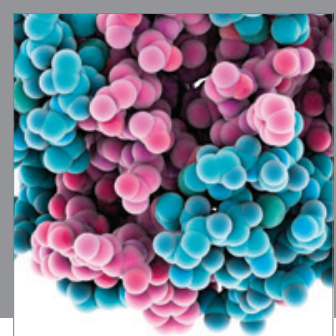

Journal of
Diabetes Research

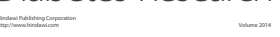

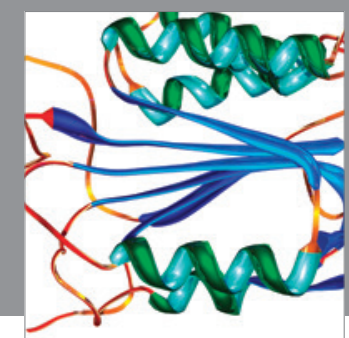

Disease Markers
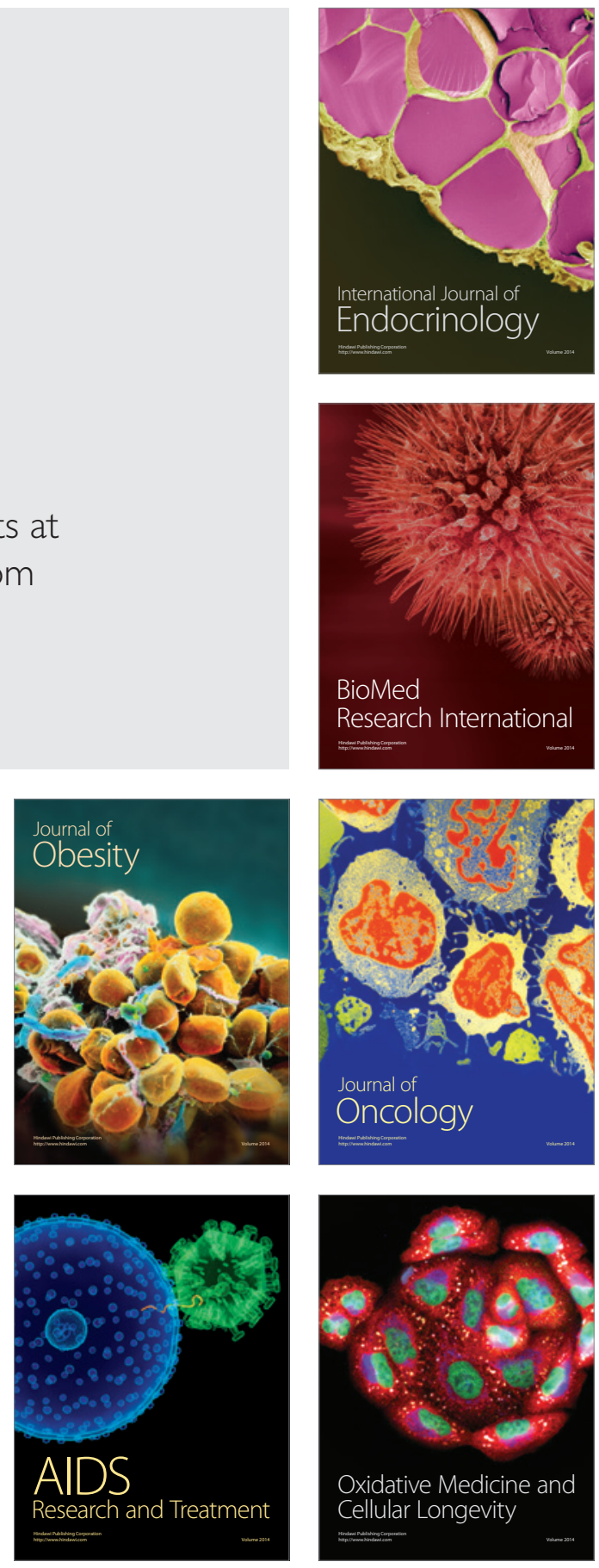